\title{
Acute and chronic effects of muscle power training on blood pressure in elderly patients with type 2 diabetes mellitus
}

\author{
Carlos Leonardo Figueiredo Machado, Cíntia Ehlers Botton, Clarissa Müller \\ Brusco, Lucinéia Orsolin Pfeifer, Eduardo Lusa Cadore \& Ronei Silveira Pinto
}

To cite this article: Carlos Leonardo Figueiredo Machado, Cíntia Ehlers Botton, Clarissa Müller Brusco, Lucinéia Orsolin Pfeifer, Eduardo Lusa Cadore \& Ronei Silveira Pinto (2019): Acute and chronic effects of muscle power training on blood pressure in elderly patients with type 2 diabetes mellitus, Clinical and Experimental Hypertension

To link to this article: https://doi.org/10.1080/10641963.2019.1590386

曲 Published online: 14 Mar 2019.

Submit your article to this journal ¿त

View Crossmark data $\asymp$ 


\title{
Acute and chronic effects of muscle power training on blood pressure in elderly patients with type 2 diabetes mellitus
}

\author{
Carlos Leonardo Figueiredo Machado , Cíntia Ehlers Botton ${ }^{\mathrm{b}, c}$, Clarissa Müller Brusco ${ }^{\mathrm{a}}$, Lucinéia Orsolin Pfeiferb, \\ Eduardo Lusa Cadorea, and Ronei Silveira Pinto ${ }^{a}$
}

aExercise Research Laboratory, School of Physical Education, Physiotherapy and Dance, Universidade Federal do Rio Grande do Sul, Porto Alegre, Rio Grande do Sul, Brazil; 'bxercise Pathophysiology Laboratory, Hospital de Clínicas de Porto Alegre, Universidade Federal do Rio Grande do Sul, Porto Alegre, Rio Grande do Sul, Brazil; 'National Institute of Science and Technology for Health Technology Assessment, Universidade Federal do Rio Grande do Sul, Porto Alegre, Rio Grande do Sul, Brazil

\begin{abstract}
The aim of the present study was to evaluate the effects of 12 weeks of muscle power training (MPT) on casual blood pressure (BP) (before and after each training session) and resting BP (pre- and post-training program) in type 2 diabetes mellitus (T2DM) elderly.

Methods: Twelve T2DM elderly individuals (68.75 \pm 7.83 years), non-insulin-dependents participated in the present study and performed the MPT program twice a week. Casual BP was measured before and after training sessions, and resting BP was measured $48 \mathrm{~h}$ before the first and $48 \mathrm{~h}$ after the last training session.

Results: Significant decrease in casual systolic (SBP) $(-7.08 \pm 4.12 \mathrm{~mm} \mathrm{Hg}$ [effect size [ES]: -1.42 to -0.11 ; $p<0.01)$ and diastolic (DBP) BP $(-3.14 \pm 1.24 \mathrm{~mm} \mathrm{Hg}$ [ES: -1.24 to -0.18 ]; $p>0.01)$ was found after training sessions, without significant effect $(p>0.05)$ of the week along time or casual BP $\times$ week interaction. No significant change in resting SBP $(-5.08 \pm 8.93 \mathrm{~mm} \mathrm{Hg}$ [ES: -0.41$] ; p=0.07)$ and DBP $(0.47 \pm 6.06 \mathrm{~mm} \mathrm{Hg}[\mathrm{ES}:+0.11] ; p=0.79)$ was found.

Conclusion: MPT was able to reduce casual BP after training sessions. However, there was no significant reduction in resting BP after MPT. Nevertheless, although not statistically significant, there were important clinical reductions in resting SBP in T2DM elderly patients.
\end{abstract}

\section{ARTICLE HISTORY}

Received 21 December 2018

Revised 8 February 2019

Accepted 18 February 2019

\section{KEYWORDS}

Systolic blood pressure; diastolic blood pressure; older adults; high-velocity resistance training; high-speed resistance training; resistance exercise

\section{Introduction}

People living with type 2 diabetes mellitus (T2DM) are increasing every year, and a substantial amount of people affected are elderly $(1,2)$. The T2DM is associated with high blood pressure (BP) and increased risk of cardiovascular disease (3-5). In addition, elderly people with T2DM exhibit greater neuromuscular impairment, such as loss of muscle mass, muscle strength and power and in functional capacity when compared to healthy elderly individuals (6-8).

It has been demonstrated that muscle power training (MPT) is an effective strategy to mitigate age-related neuromuscular impairments in muscle mass, muscle strength and power and in functional capacity of elderly individuals (9-12). The MPT is associated with specific mechanical characteristics such as the high-velocity concentric phase, low to moderate loads and a submaximal repetitions number (9-12). These training characteristics are associated with lower BP increases during the exercise performance (13-15). Recently, Miyamoto, Kamada, and Moritani (2017) reported a smaller acute BP increase during a strength exercise performed at high-velocity when compared to low velocity of contraction (15). Thus, it is possible to speculate that MPT might be an effective strategy to improve neuromuscular (i.e., muscle mass, strength, and power) and functional parameters in elderly people while inducing lower BP increases during the training session. The acute and chronic effects of traditional resistance training in T2DM individuals have been demonstrated in previous studies (16-26). However, there is a lack of information regarding the acute and chronic BP responses to an MPT program in T2DM elderly individuals. The reduction in BP levels induced by the exercise has a clinical importance, especially because it contributes to lower exposure to the damages and risks associated with higher BP values.

The T2DM is associated with neuromuscular and functional impairments, and T2DM elderly individuals exhibit increased risk of high BP and cardiovascular disease, therefore, it is possible that these individuals might benefit from an MPT program by improving their neuromuscular and functional performance while inducing reduced $\mathrm{BP}$ increases during the exercise execution and reduced BP levels after the training session. In addition, as a traditional resistance training program was able to induce a chronic alteration in BP levels (16-22), it is possible to speculate that the MPT program might also induce chronic decrease in BP levels. To the best of the authors' knowledge, no previous studies have evaluated the acute and chronic effects of an MPT program on BP in elderly with T2DM. Therefore, the aims of this study were: (a) to evaluate the acute effects of MPT sessions on 
casual BP along 12 weeks of training and (b) to investigate the effect of 12 weeks of MPT on resting BP in elderly with T2DM. Our hypotheses were that MPT would induce significant acute BP reduction following each training session and a significant decrease in the resting $\mathrm{BP}$ after 12 weeks of intervention.

\section{Materials and methods}

\section{Experimental purpose}

The purpose of the study was to compare the chronic effects of 12 weeks of MPT in neuromuscular and functional parameters of T2DM elderly individuals. In the present study, the acute (training sessions) and chronic effects (after 12 weeks of training) of MPT in casual and resting BP of T2DM elderly were verified. The present study is part of a randomized clinical trial - Diabetes Resistance Training Adaptations in Elderly (NCT02548000).

\section{Participants}

Twelve elderly men and women (prior control group; convenience sample) with T2DM (27) participated in 12 weeks of MPT. Participants inclusion criteria were the diabetes diagnosis by $\mathrm{HbAlc}$ values $\geq 6.5 \%$, non-insulin users, body mass index between 18.5 and $34.9 \mathrm{~kg} / \mathrm{m}^{2}$, non-smokers, untrained for at least six months prior to the study participation and all participants should have medical release certificate for regular physical exercise. Exclusion criteria were myocardial infarction (within past 6 months), any unstable cardiovascular chronic condition, neuromuscular disease, clinical depression and microvascular complications due to T2DM. The participants were informed about purpose, procedures, and risks of study participation, and written informed consent was obtained from all participants. All procedures were approved by the University Institutional Review Board and conducted in accordance with the Declaration of Helsinki.

\section{Muscle power training}

The MPT program was performed two times per week on non-consecutive days over 12 weeks. Eight exercises were performed in the following order: knee extension, pulldown, knee flexion, elbow flexion, hip abduction, elbow extension, hip adduction, and finished with abdominal exercise. Three sets of each exercise were performed using 10-8, 8-6 and 6-4 repetitions in months 1,2 and 3 , respectively, accordingly to the submaximal intensity, and $3 \mathrm{~min}$ of rest interval between sets were allowed. The participants were instructed to perform the concentric phase "as fast as possible" and the eccentric phase over 2-3 s for all exercises (9-12). Care was taken to not induce concentric muscular failure (i.e., maximal repetitions) in any exercise performed. This procedure is recommended for MPT and it avoids great increases in BP induced by repetitions to failure (14). All training sessions were supervised by the same researches, and the participants were in high supervisor-to-subjects ratio (1:2) (12).

\section{Blood pressure assessment}

The systolic (SBP) and diastolic (DBP) BP were measured with an automatic arm BP monitor (OMRON, model HEM-7113) in the left arm. The resting and casual BP were always verified in the morning. The BP assessed before and after each training session was defined as casual BP, and before and after 12 weeks of MPT training was defined as resting BP. The casual BP was measured before and after each training session after 5 min rest in the seated position. For the analyses of the casual BP, it was considered the mean value of the SBP and DBP measured before and after training of the two training sessions of each week. We chose to use this method in order to avoid any great differences that could occur between two training sessions, which could influence the possible effects of the MPT in casual BP. The resting $\mathrm{BP}$ was evaluated at $48 \mathrm{~h}$ before the first training session and at $48 \mathrm{~h}$ after the last training session after $10 \mathrm{~min}$ rest. All measurements were performed by the same evaluator using the same procedures. Participants were instructed to do not ingest caffeinated products and absent from strenuous physical exercise. In the last personal contact with the participants, they were informed about the importance of caffeinated products and strenuous exercises absences in moments previous the evaluations. In addition, the participants were remembered by phone call about these instructions $24 \mathrm{~h}$ prior the day of the assessments. In addition, the participants were requested to weekly inform about their medication intakes.

\section{Data analysis}

The results are expressed as a mean \pm SD and $95 \%$ confidence interval. The normality of the data was assessed using the ShapiroWilk test. To compare the main effects of casual BP (casual BP in each week, between the 12 weeks and casual $\mathrm{BP} \times$ week interaction), a two-way analysis of variance (ANOVA) with repeated measures was used. A paired sample t-test was used to compare resting BP before and after 12 weeks of MPT. The effect size (ES) was calculated according to Cohen, and values of 0.20 were considered small effect, 0.50 moderate effect and $\geq 0.80$ large effect (28). The level of significance was set at $\alpha<0.05$. All analyses were performed in the Statistical Package for Social Science (SPSS) software version 20.0.

\section{Results}

\section{Participants characteristics}

All participants (five males and seven females) completed the 12 weeks of MPT and the adherence to training sessions was 95.50\%. The sample characteristics are reported in Table 1. Six participants were hypertensive and other six were nonhypertensive. Three hypertensive participants changed one antihypertensive medication dose over 12 MPT weeks (beta blocker reduction, angiotensin-converting enzyme inhibitor increment, and angiotensin II receptor antagonists increment, respectively). No adverse events of hypoglycemia or hypotension occurred during any MPT sessions and no discomfort was reported during the training sessions. 
Table 1. Characteristics of the sample $(n=12)$.

\begin{tabular}{lc}
\hline & Mean \pm SD \\
\hline Age (years) & $68.75 \pm 7.83$ \\
Total Body Mass (kg) & $73.23 \pm 24.46$ \\
Height (cm) & $160.48 \pm 8.56$ \\
Body Mass Index $\left(\mathrm{kg} / \mathrm{m}^{2}\right)$ & $28.22 \pm 3.78$ \\
Glycemic Hemoglobin (\%) & $7.11 \pm 0.83$ \\
Duration of Type 2 Diabetes Mellitus (years) & $11.69 \pm 7.39$ \\
Systolic Blood Pressure (mm Hg) & $125.00 \pm 15.20$ \\
Diastolic Blood Pressure (mm Hg) & $68.28 \pm 3.72$ \\
Medical Treatment (n) & \\
Sulfonilureias & 4 \\
Metformin & 10 \\
Dipeptidyl peptidase-4 inhibitor & 2 \\
Sodium-glucose 2 cotransporter inhibitors & 1 \\
Diuretics & 1 \\
Angiotensin Converting Enzyme Inhibitors & 3 \\
Angiotensin II Receptor Antagonists & 2 \\
Antagonists of the Calcium Channels & 2 \\
Acetylsalicylic acid (aspirin) & 6 \\
Betablockers & 2 \\
\hline
\end{tabular}

\section{Casual blood pressure}

Casual BP values are presented in Table 2. There were significant reductions in casual SBP $(\mathrm{p}<0.01)$ and DBP $(\mathrm{p}<0.01)$ from preto post-training of each of the 12 weeks of MPT, but no significant ( $p>0.05$ ) effect of the week along the MPT or casual BP $\times$ week interaction $(p>0.05)$ was observed for SBP or DBP. The average acute reduction observed after MPT sessions in casual SBP was $-7.08 \pm 4.12 \mathrm{~mm} \mathrm{Hg}$ (ES: -1.42 to -0.11 ), while for casual DBP was $-3.14 \pm 1.24 \mathrm{~mm} \mathrm{Hg}$ (ES: -1.24 to -0.18 ). When analyzing only BP change from hypertensive participants, the casual SBP decreased $-7.96 \pm 5.91 \mathrm{~mm} \mathrm{Hg}$, and DBP decreased $-3.28 \pm$ $1.92 \mathrm{~mm} \mathrm{Hg}$. For non-hypertensive participants, the mean changes were $-3.46 \pm 4.06 \mathrm{~mm} \mathrm{Hg}$ and $-2.10 \pm 1.08 \mathrm{~mm} \mathrm{Hg}$ for casual SBP and DBP, respectively. As shown in Table 2, there were significant changes in SBP and DBP between pre and post-MPT sessions with moderate to large ES in most of the weeks.

\section{Resting blood pressure}

The resting $\mathrm{BP}$ values are presented in Table 3 , and the individual chronic responses for resting SBP and DBP are presented in Figure 1. After 12 weeks of MPT, there was no significant change in resting SBP ( $p=0.07$; ES: -0.41$)$ or DBP $(\mathrm{p}=0.79$; ES: +0.11$)$. The average change in resting SBP was $-5.08 \pm 9.83 \mathrm{~mm} \mathrm{Hg}$ and $+0.47 \pm 6.06 \mathrm{~mm} \mathrm{Hg}$ for DBP. Considering only hypertensive participants, the average change for SBP was $-8.89 \pm 11.29 \mathrm{~mm} \mathrm{Hg}$ and $0.00 \pm$ $7.17 \mathrm{~mm} \mathrm{Hg}$ for DBP. For the non-hypertensive participants, the average change was $-1.28 \pm 3.67$ and $+0.94 \pm 5.38 \mathrm{~mm} \mathrm{Hg}$ for SBP and DBP, respectively.

\section{Discussion}

The main finding of the present study was that significant reductions in SBP and DBP were found immediately after an MPT session with no differences within training weeks. In addition, no significant alteration in resting BP was found after 12 weeks of MPT and, although not statistically different from the before training values, these reductions might be considerate clinically relevant, especially in the hypertensive participants. To the best of the authors' knowledge, this was the first study investigating the acute and chronic effects of an MPT program on BP of the elderly with T2DM.

The results found in the present study for casual BP are in agreement with previous studies that observed acute BP reduction after aerobic or traditional resistance training sessions in

Table 2. Casual systolic (SBP) and diastolic blood pressure (DBP) pre- and post-session over the weeks $(n=10)$.

\begin{tabular}{|c|c|c|c|c|c|c|c|c|}
\hline Weeks of MPT & $\begin{array}{c}\text { SBP } \\
\text { pre-session } \\
(\mathrm{mm} \mathrm{Hg})\end{array}$ & $\begin{array}{c}\text { SBP } \\
\text { post-session } \\
(\mathrm{mm} \mathrm{Hg})\end{array}$ & $\begin{array}{c}\text { SBP } \\
\text { change } \\
(\mathrm{mm} \mathrm{Hg})\end{array}$ & ES & $\begin{array}{c}\text { DBP } \\
\text { pre-session }(\mathrm{mm} \mathrm{Hg})\end{array}$ & $\begin{array}{c}\text { DBP } \\
\text { post-session }(\mathrm{mm} \mathrm{Hg})\end{array}$ & $\begin{array}{c}\text { DBP } \\
\text { change } \\
\text { (mm Hg) }\end{array}$ & ES \\
\hline 1 & $131.25 \pm 12.93$ & $124.30 \pm 14.13^{*}$ & $\begin{array}{r}-6.95 \pm 11.00 \\
(-14.82 \text { to } 0.92)\end{array}$ & -0.51 & $78.20 \pm 3.21$ & $73.65 \pm 4.10^{*}$ & $\begin{array}{c}-4.55 \pm 4.20 \\
(-7.55 \text { to }-1.54)\end{array}$ & -1.24 \\
\hline 2 & $129.90 \pm 17.38$ & $123.50 \pm 10.37^{*}$ & $\begin{array}{l}-9.40 \pm 19.23 \\
(-23.15 \text { to } 4.35)\end{array}$ & -0.57 & $77.15 \pm 5.43$ & $74.25 \pm 5.68^{*}$ & $\begin{array}{r}-2.90 \pm 5.30 \\
(-6.69 \text { to } 0.89)\end{array}$ & -0.52 \\
\hline 3 & $130.05 \pm 14.12$ & $124.85 \pm 13.57^{*}$ & $\begin{array}{r}-5.20 \pm 9.07 \\
(-11.68 \text { to } 1.28)\end{array}$ & -0.38 & $77.80 \pm 5.19$ & $73.60 \pm 6.10^{*}$ & $\begin{array}{c}-4.20 \pm 2.61 \\
(-6.07 \text { to }-2.32)\end{array}$ & -0.74 \\
\hline 4 & $130,90 \pm 19.61$ & $122.90 \pm 11.17^{*}$ & $\begin{array}{r}-8.00 \pm 15.79 \\
(-19.30 \text { to } 3.30)\end{array}$ & -0.52 & $76.80 \pm 6.75$ & $72.35 \pm 6.81^{*}$ & $\begin{array}{c}-4.45 \pm 4.81 \\
(-7.89 \text { to }-1.00)\end{array}$ & -0.66 \\
\hline 5 & $132.00 \pm 7.84$ & $119.60 \pm 10.01^{*}$ & $\begin{array}{l}-12.40 \pm 6.93 \\
(-17.35 \text { to }-7.44)\end{array}$ & -1.39 & $77.60 \pm 5.73$ & $73.15 \pm 8.05^{*}$ & $\begin{array}{r}-4.45 \pm 6.26 \\
(-8.92 \text { to } 0.02)\end{array}$ & -0.65 \\
\hline 6 & $131.80 \pm 12.59$ & $120.60 \pm 10.76^{*}$ & $\begin{array}{l}-11.20 \pm 16.02 \\
(-22.66 \text { to } 0.26)\end{array}$ & -0.96 & $75.00 \pm 7.09$ & $72.20 \pm 7.14^{*}$ & $\begin{array}{r}-2.80 \pm 6.81 \\
(-7.67 \text { to } 2.07)\end{array}$ & -0.39 \\
\hline 7 & $137.05 \pm 11.08$ & $123.55 \pm 7.94^{*}$ & $\begin{array}{c}-13.50 \pm 9.42 \\
(-20.24 \text { to }-6.76)\end{array}$ & -1.42 & $77.00 \pm 8.87$ & $72.50 \pm 8.13^{*}$ & $\begin{array}{c}-4.50 \pm 4.18 \\
(-7.49 \text { to }-1.50)\end{array}$ & -0.53 \\
\hline 8 & $129.55 \pm 14.80$ & $124.85 \pm 10.99^{*}$ & $\begin{array}{c}-4.70 \pm 9.07 \\
(-11.18 \text { to } 1.78)\end{array}$ & -0.36 & $75.95 \pm 9.42$ & $74.20 \pm 6.41^{*}$ & $\begin{array}{c}-1.75 \pm 8.57 \\
(-7.88 \text { to } 4.38)\end{array}$ & -0.22 \\
\hline 9 & $129.70 \pm 12.64$ & $127.35 \pm 8.09^{*}$ & $\begin{array}{r}-2.35 \pm 11.45 \\
(-10.54 \text { to } 5.84)\end{array}$ & -0.23 & $78.30 \pm 7.68$ & $75.45 \pm 4.25^{*}$ & $\begin{array}{r}-2.85 \pm 5.87 \\
(-7.05 \text { to } 1.35)\end{array}$ & -0.48 \\
\hline 10 & $127.25 \pm 17.15$ & $125.45 \pm 11.20^{*}$ & $\begin{array}{l}-1.80 \pm 9.53 \\
(-8.62 \text { to } 5.02)\end{array}$ & -0.13 & $76.20 \pm 5.68$ & $75.05 \pm 7.38^{*}$ & $\begin{array}{r}-1.15 \pm 5.09 \\
(-4.79 \text { to } 2.49)\end{array}$ & -0.18 \\
\hline 11 & $132.75 \pm 14.17$ & $124.65 \pm 12.18^{*}$ & $\begin{array}{c}-8.10 \pm 7.47 \\
(-13.44 \text { to }-2.75)\end{array}$ & -0.61 & $76.75 \pm 8.29$ & $74.95 \pm 9.56^{*}$ & $\begin{array}{r}-1.80 \pm 3.74 \\
(-4.47 \text { to } 0.87)\end{array}$ & -0.20 \\
\hline 12 & $125.90 \pm 9.45$ & $124.60 \pm 14.74^{*}$ & $\begin{array}{l}-1.30 \pm 10.22 \\
(-8.61 \text { to } 6.01)\end{array}$ & -0.11 & $75.25 \pm 9.71$ & $72.95 \pm 5.29^{*}$ & $\begin{array}{r}-2.30 \pm 6.36 \\
(-6.85 \text { to } 2.25)\end{array}$ & -0.31 \\
\hline
\end{tabular}

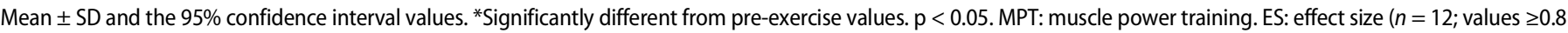
were considered large, between 2.0 and 8.0 moderate and $\leq 0.2$ small). Two participants were excluded from the two-way ANOVA because of missing data. 
Table 3. Resting blood pressure pre and post-training $(n=12)$.

\begin{tabular}{lccccc}
\hline & Pre-training & Post-training & Mean change & $p$ & ES \\
\hline $\begin{array}{l}\text { Systolic } \\
\text { Blood }\end{array}$ & $125.00 \pm 15.1$ & $119.92 \pm 9.83$ & $-5.08 \pm 8.93$ & 0.07 & -0.41 \\
$\quad \begin{array}{l}\text { Pressure } \\
\text { (mm Hg) }\end{array}$ & & & $(-10.75$ to 0.59$)$ & & \\
$\begin{array}{l}\text { Diastolic } \\
\text { Blood }\end{array}$ & $68.28 \pm 3.72$ & $68.75 \pm 5.12$ & $\begin{array}{c}0.47 \pm 6.06 \\
(-3.37 \text { to } 4.32)\end{array}$ & 0.79 & +0.11 \\
$\quad \begin{array}{l}\text { Pressure } \\
\text { (mm Hg) }\end{array}$ & & & & & \\
\hline
\end{tabular}

Mean \pm SD and the $95 \%$ confidence interval values. ES: effect size (values $\geq 0.8$ were considered large, between 2.0 and 8.0 moderate and $\leq 0.2$ small).

T2DM individuals $(23-25,29)$. Additionally, it is important to point out that T2DM subjects might have a lower BP response to an exercise session compared to healthy individuals $(25,30)$; thus, interventions that contribute to BP decrease in T2DM people have been considered clinically relevant. Moreover, a greater average reduction of BP was observed in the hypertensive individuals than in non-hypertensive individuals. Therefore, according to the results of the present study, elderly individuals with $\mathrm{T} 2 \mathrm{DM}$ in antihypertensive drug treatment can benefit from the effects of MPT for acute reduction of BP. These results are of great importance as it demonstrates that the MPT used in the present study might be an interesting training strategy as it contributes to lower exposure to the damages and risks associated with higher $\mathrm{BP}$ values.

Regarding MPT and resting BP, only two studies that evaluated the chronic effects of training in resting BP were found $(31,32)$. In the study of Valls et al. (2014), no significant changes in resting BP were observed after 12 weeks of MPT (32). In another study, Kanegusuku et al. (2011) observed a significant decrease in resting SBP for the MPT and for the non-exercise groups after 16 weeks of intervention, whereas DBP was not significantly changed. However, according to the authors, these results possibly did not represent an effect of training as these responses were similar between the training and the non-training groups (31). Regarding traditional resistance training (e.g., use of slow to moderate movement velocity), previous studies have observed a significant chronic reduction in resting BP in T2DM individuals after exercise interventions (11-22,26), while other studies did not (33-37). It is worth noting that most of the studies that observed a significant chronic effect of traditional resistance training on resting $\mathrm{BP}$ in T2DM subjects used a higher weekly frequency of training (i.e., three times) (17-19,22,26,33) and/or longer intervention period ( $>12$ weeks) (16-20,26,33). Moreover, these studies used different protocols regarding volume (repetitions $\mathrm{x}$ sets), intensity (\% of maximum/load) and exercises performed. Thus, it is possible that the distinctive characteristics of the training program used in the present study and previous studies that have observed chronic BP reduction after traditional resistance training programs might have contributed to the different results (38-41).

Lower glycemic control and longer duration of the T2DM may indicate greater exposure to hyperglycemia damage and, therefore, have an impact on the acute and chronic BP changes after training (24,30,42-44). Thus, differences between studies regarding these variables might also have contributed to the different results. Previous studies have emphasized the greater reduction of $\mathrm{BP}$ after exercise, especially observed in individuals with higher initial $\mathrm{BP}$ values $(\geq 130 / \geq 80 \mathrm{~mm} \mathrm{Hg})$ $(40,45,46)$. It is possible that the mean initial BP observed in the participants of the present study $(<130 /<80 \mathrm{~mm} \mathrm{Hg})$ might have contributed to the absence of a statistically significant chronic benefit after MPT in resting BP.

It is important to observe that $\mathrm{BP}$ reductions are more commonly observed following aerobic training programs and some studies show no chronic BP reductions after resistance exercise on T2DM people $(33-37,46)$. However, considering that the performance of strength exercises such as MPT is also extremely necessary for older adults, due to documented neuromuscular and functional benefits of these interventions (9-12), it is important to have the knowledge about the possible effects of an MPT on BP besides the neuromuscular and functional benefits that have been already documented (10-12). Although there was no statistical reduction in resting BP after 12 weeks of MPT, the present study exhibits important clinical perspectives. The mean change observed in the present study for resting SBP is highly relevant since an SBP change of $5 \mathrm{~mm} \mathrm{Hg}$ and $2 \mathrm{~mm} \mathrm{Hg}$ in DPB are associated with a lower risk for cerebrovascular $(-14 \%$ and $-15 \%$, respectively) and cardiovascular disease $(-9 \%$ and $-6 \%$, respectively) $(47,48)$. Moreover, individuals with T2DM with high SBP values have a higher risk for cardiovascular disease than individuals with lower SBP values $(49,50)$, and in the present study, the hypertensive individuals showed greater decreases after the MPT sessions. Therefore, even minor changes in resting BP might be of great clinical relevance for this population.
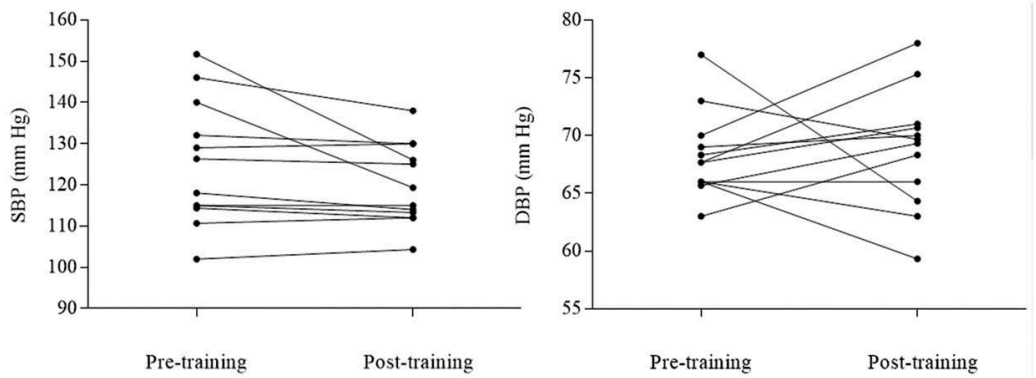

Figure 1. Individual responses of resting systolic blood pressure (SBP) (a) and resting diastolic blood pressure (DBP) (b) pre and post-training. 
Possible limitations of the present study are the small number of participants and absence of a control group. However, it is noteworthy that this is the first study investigating the acute and chronic effects of MPT in BP in elderly people with T2DM. In addition, the present results show important changes in BP after MPT sessions, especially in hypertensive individuals and that this training model may be beneficial for BP control in elderly individuals with T2DM.

\section{Conclusion and future directions}

In summary, the MPT intervention used in the present study was able to induce significant reductions in casual BP after training sessions during 12 weeks of intervention, without differences within the training weeks. However, there was no significant chronic effect induced by MPT on resting SBP and DBP. Nevertheless, important clinical reductions of BP were observed for elderly patients with T2DM, especially in the hypertensive individuals. From a practical point of view, MPT might be recommended as a training intervention, as it induces acute reductions in the SBP and DBP. In addition, these results are important as this type of intervention (i.e., MPT) is also able to induce significant neuromuscular and functional enhancements in elderly diabetic individuals. Further studies might investigate MPT programs using higher weekly training frequency ( $>3$ training session per week) and longer training duration ( $>12$ weeks) to elucidate if MPT with different characteristics than the present study might induce different chronic BP adaptations in the elderly individuals with T2DM.

\section{Acknowledgments}

We would like to thank CNPq (Conselho Nacional de Desenvolvimento Científico e Tecnológico) and CAPES (Coordenação de Aperfeiçoamento de Pessoal de Nível Superior) for their financial support. The authors are also grateful to UFRGS and all participants of this research and made this project possible. This research did not receive any specific grant from funding agencies in the public, commercial, or not-for-profit sectors.

\section{Authors' Contributions}

C. L. F. M., C. E. B., and R. S. P. designed the study, obtained the funding, researched and analyzed data, wrote the manuscript, contributed to the discussion, reviewed and edited the manuscript; L. O. P. researched and analyzed data and contributed to the discussion; C. M. B. and E. L. C. contributed to the discussion, reviewed and edited the manuscript. All authors approve the definitive version of manuscript.

\section{Disclosure of interest}

The authors report no conflict of interest.

\section{References}

1. Guariguata L, Whiting DR, Hambleton I, Beagley J, Linnenkamp U, Shaw JE. Global estimates of diabetes prevalence for 2013 and projections for 2035. Diabetes Res Clin Pract. 2014;103:137-49. doi:10.1016/j.diabres.2013.11.002.

2. International Diabetes Federation. IDF diabetes atlas. 7th ed. Brussels, Belgium: International Diabetes Federation; 2015.
3. Hypertension in Diabetes Study (HDS): I. Prevalence of hypertension in newly presenting type 2 diabetic patients and the association with risk factors for cardiovascular and diabetic complications. J Hypertens. 1993;11:309-17.

4. Hypertension in Diabetes Study (HDS): II. Turner R, Holman R, Stratton I, Cull C, Frighi V, Manley S, Matthews D, Neil A, McElroy H, Kohner E, et al. Increased risk of cardiovascular complications in hypertensive type 2 diabetic patients. J Hypertens. 1993;11:319-25. Erratum in: J Hypertens. 1993;11:681.

5. Shah AD, Langenberg C, Rapsomaniki E, Denaxas S, PujadesRodriguez M, Gale CP, Deanfield J, Smeeth L, Timmis A, Hemingway $\mathrm{H}$. Type 2 diabetes and incidence of cardiovascular diseases: a cohort study in 1.9 million people. Lancet Diabetes Endocrinol. 2015;3:105-13. doi:10.1016/S2213-8587(14)70219-0.

6. Leenders $M$, Verdijk LB, van der Hoeven L, Adam JJ, van Kranenburg J, Nilwik R, van Loon LJ. Patients with type 2 diabetes show a greater decline in muscle mass, muscle strength, and functional capacity with aging. J Am Med Dir Assoc. 2013;14:585-92. doi:10.1016/j.jamda.2013.02.006.

7. Park SW, Goodpaster BH, Strotmeyer ES, Kuller LH, Broudeau R, Kammerer C, de Rekeneire N, Harris TB, Schwartz AV, Tylavsky FA, et al. Health, aging, and body composition study. Accelerated loss of skeletal muscle strength in older adults with type 2 diabetes: the health, aging, and body composition study. Diabetes Care. 2007;30:1507-12. doi:10.2337/dc06-2537.

8. Kalyani RR, Tra Y, Yeh HC, Egan JM, Ferrucci L, Brancati FL. Quadriceps strength, quadriceps power, and gait speed in older U.S. adults with diabetes mellitus: results from the national health and nutrition examination survey, 1999-2002. J Am Geriatr Soc. 2013;61:769-75. doi:10.1111/jgs.12204.

9. Pereira A, Izquierdo M, Silva AJ, Costa AM, Bastos E, GonzálezBadillo JJ, Marques MC. Effects of high-speed power training on functional capacity and muscle performance in older women. Exp Gerontol. 2012;47:250-55. doi:10.1016/j.exger.2011.12.010.

10. Radaelli R, Brusco CM, Lopez P, Rech A, Machado CLF, Grazioli R, Müller DC, Cadore EL, Pinto RS. Higher muscle power training volume is not determinant for the magnitude of neuromuscular improvements in elderly women. Exp Gerontol. 2018;3:15-22. doi:10.1016/j.exger.2018.04.015.

11. Ramírez-Campillo R, Castillo A, de la Fuente CI, Campos-Jara C, Andrade DC, Álvarez C, Martínez C, Castro-Sepúlveda M, Pereira A, Marques MC, et al. High-speed resistance training is more effective than low-speed resistance training to increase functional capacity and muscle performance in older women. Exp Gerontol. 2014;58:51-57. doi:10.1016/j.exger.2014.07.001.

12. Ramírez-Campillo R, Martínez C, de La Fuente CI, Cadore EL, Marques MC, Nakamura FY, Loturco I, Caniuqueo A, Cañas R, Izquierdo M. High-speed resistance training in older women: the role of supervision. J Aging Phys Act. 2017;25:1-9. doi:10.1123/ japa.2015-0122.

13. Lamotte M, Fleury F, Pirard M, Jamon A, van de Borne P. Acute cardiovascular response to resistance training during cardiac rehabilitation: effect of repetition speed and rest periods. Eur J Cardiovasc Prev Rehabil. 2010;17:329-36. doi:10.1097/ HJR.0b013e328332efdd.

14. Lamotte M, Niset G, Van de Borne P. The effect of different intensity modalities of resistance training on beat-to-beat blood pressure in cardiac patients. Eur J Cardiovasc Prev Rehabil. 2005;12:12-17.

15. Miyamoto $\mathrm{T}$, Kamada $\mathrm{H}$, Moritani T. Acute cardiovascular responses to multiple sets of high-velocity resistance exercise in healthy adults. Res Sports Med. 2017;25:495-504. doi:10.1080/ 15438627.2017.1365298.

16. Arora E, Shenoy S, Sandhu JS. Effects of resistance training on metabolic profile of adults with type 2 diabetes. Indian J Med Res. 2009;129:515-19.

17. Bacchi E, Negri C, Zanolin ME, Milanese C, Faccioli N, Trombetta M, Zoppini G, Cevese A, Bonadonna RC, Schena F, et al. Metabolic effects of aerobic training and resistance training 
in type 2 diabetic subjects: a randomized controlled trial (the RAED2 study). Diabetes Care. 2012;35:676-82. doi:10.2337/ dc11-1655.

18. Castaneda C, Layne JE, Munoz-Orians L, Gordon PL, Walsmith J, Foldvari M, Roubenoff R, Tucker KL, Nelson ME. A randomized controlled trial of resistance exercise training to improve glycemic control in older adults with type 2 diabetes. Diabetes Care. 2002;25:2335-41.

19. Cauza E, Hanusch-Enserer U, Strasser B, Ludvik B, MetzSchimmerl S, Pacini G, Wagner O, Georg P, Prager R, Kostner K, et al. The relative benefits of endurance and strength training on the metabolic factors and muscle function of people with type 2 diabetes mellitus. Arch Phys Med Rehabil. 2005;86:1527-33. doi:10.1016/j.apmr.2005.01.007.

20. Cohen ND, Dunstan DW, Robinson C, Vulikh E, Zimmet PZ, Shaw JE. Improved endothelial function following a 14-month resistance exercise training program in adults with type 2 diabetes. Diabetes Res Clin Pract. 2008;79:405-11. doi:10.1016/j. diabres.2007.09.020.

21. Dunstan DW, Puddey IB, Beilin LJ, Burke V, Morton AR, Stanton KG. Effects of a short-term circuit weight training program on glycaemic control in NIDDM. Diabetes Res Clin Pract. 1998;40:53-61.

22. Kadoglou NP, Fotiadis G, Athanasiadou Z, Vitta I, Lampropoulos S, Vrabas IS. The effects of resistance training on ApoB/ApoA-I ratio, $L p(a)$ and inflammatory markers in patients with type 2 diabetes. Endocrine. 2012;42:561-69. doi:10.1007/ s12020-012-9650-y.

23. Sales MM, Russo P, Moreira SR, Santana H, Moraes JF, Asano RY, Motta DF, Dullius J, Simões HG, Campbell C. Resistance exercise elicits acute blood pressure reduction in type 2 diabetics. J Exercise Physiol Online. 2012;15:98-109.

24. Simões GC, Moreira SR, Kushnick MR, Simões HG, Campbell CS. Postresistance exercise blood pressure reduction is influenced by exercise intensity in type- 2 diabetic and nondiabetic individuals. J Strength Cond Res. 2010;24:1277-84. doi:10.1519/ JSC.0b013e3181d67488.

25. Simões HG, Asano RY, Sales MM, Browne RAV, Arsa G, MottaSantos D, Puga GM, Lima LCJ, Campbell CSG, Franco OL. Type 2 diabetes elicits lower nitric oxide, bradykinin concentration and kallikrein activity together with higher desArg9-BK and reduced post-exercise hypotension compared to non-diabetic condition. PLoS One. 2013;8:e80348. doi:10.1371/journal.pone.0080348.

26. Strasser B, Haber P, Strehblow C, Cauza E. The benefit of strength training on arterial blood pressure in patients with type 2 diabetes mellitus measured with ambulatory 24-hour blood pressure systems. Wien Med Wochenschr. 2008;158:379-84. doi:10.1007/ s10354-008-0550-y.

27. Botton CE, Umpierre D, Rech A, Pfeifer LO, Machado CLF, Teodoro JL, Dias AS, Pinto RS. Effects of resistance training on neuromuscular parameters in elderly with type 2 diabetes mellitus: A randomized clinical trial. Exp Gerontol. 2018;113:141-49. doi:10.1016/j.exger.2018.10.001.

28. Cohen J. Statistical power analysis for the behavioral sciences. Hillsdale, NJ: Lawrence Erlbaum; 1988.

29. Morais PK, Campbell CS, Sales MM, Motta DF, Moreira SR, Cunha VN, Benford RE, Simões HG. Acute resistance exercise is more effective than aerobic exercise for $24 \mathrm{~h}$ blood pressure control in type 2 diabetics. Diabetes Metab. 2011;37:112-17. doi:10.1016/j.diabet.2010.08.008.

30. Motta DF, Lima LC, Arsa G, Russo PS, Sales MM, Moreira SR, Morais PK, Almeida WS, Araujo RC, Moraes MR, et al. Effect of type 2 diabetes on plasma kallikrein activity after physical exercise and its relationship to post-exercise hypotension. Diabetes Metab. 2010;36:363-68. doi:10.1016/j.diabet.2010.03.008.

31. Kanegusuku H, Queiroz AC, Chehuen MR, Costa LA, Wallerstein LF, Mello MT, Ugrinowitsch C, Forjaz CL. Strength and power training did not modify cardiovascular responses to aerobic exercise in elderly subjects. Braz J Med Biol Res. 2011;44:864-70.
32. Valls MRB, Dimauro I, Brunelli A, Tranchita E, Ciminelli E, Caserotti P, Duranti G, Sabatini S, Parisi P, Parisi A, et al. Explosive type of moderate-resistance training induces functional, cardiovascular, and molecular adaptations in the elderly. Age (Dordr). 2014;36:759-72. doi:10.1007/s11357-013-9584-1.

33. Dunstan DW, Daly RM, Owen N, Jolley D, De Courten M, Shaw J, Zimmet P. High-intensity resistance training improves glycemic control in older patients with type 2 diabetes. Diabetes Care. 2002;25:1729-36.

34. Geirsdottir OG, Arnarson A, Briem K, Ramel A, Jonsson PV, Thorsdottir I. Effect of 12-week resistance exercise program on body composition, muscle strength, physical function, and glucose metabolism in healthy, insulin-resistant, and diabetic elderly Icelanders. J Gerontol A Biol Sci Med Sci. 2012;67:1259-65. doi:10.1093/gerona/gls096.

35. Eriksson J, Taimela S, Eriksson K, Parviainen S, Peltonen J, Kujala U. Resistance training in the treatment of non-insulindependent diabetes mellitus. Int J Sports Med. 1997;18:242-46. doi:10.1055/s-2007-972627.

36. de Oliveira VN, Bessa A, Jorge ML, Oliveira RJ, de Mello MT, De Agostini GG, Jorge PT, Espindola FS. The effect of different training programs on antioxidant status, oxidative stress, and metabolic control in type 2 diabetes. Appl Physiol Nutr Metab. 2012;37:334-44. doi:10.1139/h2012-004.

37. Sigal RJ, Kenny GP, Boulé NG, Wells GA, Prud'homme D, Fortier M, Reid RD, Tulloch H, Coyle D, Phillips P, et al. Effects of aerobic training, resistance training, or both on glycemic control in type 2 diabetes: a randomized trial. Ann Intern Med. 2007;147:357-69.

38. Casonatto J, Goessler KF, Cornelissen VA, Cardoso JR, Polito MD. The blood pressure-lowering effect of a single bout of resistance exercise: A systematic review and meta-analysis of randomized controlled trials. Eur J Prev Cardiol. 2016;23:1700-14. doi:10.1177/2047487316664147.

39. Figueiredo T, de Salles BF, Dias I, Reis VM, Fleck SJ, Simão R. Acute hypotensive effects after a strength training session: A review. Int Sport Med J. 2014;15:308-29.

40. MacDonald HV, Johnson BT, Huedo-Medina TB, Livingston J, Forsyth KC, Kraemer WJ, Farinatti PT, Pescatello LS. Dynamic resistance training as stand-alone antihypertensive lifestyle therapy: a meta analysis. J Am Heart Assoc. 2016;5:e003231. doi:10.1161/ JAHA.116.003231.

41. Pescatello LS, MacDonald HV, Lamberti L, Johnson BT. Exercise for hypertension: a prescription update integrating existing recommendations with emerging research. Curr Hypertens Rep. 2015;17:87. doi:10.1007/s11906-015-0600-y.

42. Carnethon MR, Jacobs DR Jr, Sidney S, Liu K. CARDIA study. Influence of autonomic nervous system dysfunction on the development of type 2 diabetes: the CARDIA study. Diabetes Care. 2003;26:3035-41.

43. Cleland SJ, Petrie JR, Small M, Elliott HL, Connell JM. Insulin action is associated with endothelial function in hypertension and type 2 diabetes. Hypertension. 2000;35:507-11.

44. Stabler T, Kenjale A, Ham K, Jelesoff N, Allen J. Potential mechanisms for reduced delivery of nitric oxide to peripheral tissues in diabetes mellitus. Ann N Y Acad Sci. 2010;1203:101-06. doi:10.1111/j.1749-6632.2010.05599.x.

45. Brito LC, Queiroz ACC, Forjaz CLM. Influence of population and exercise protocol characteristics on hemodynamic determinants of post-aerobic exercise hypotension. Braz $\mathrm{Jl} \mathrm{Med} \mathrm{and} \mathrm{Biol} \mathrm{Res.}$ 2014;47:626-36.

46. Cornelissen VA, Smart NA. Exercise training for blood pressure: a systematic review and meta-analysis. J Am Heart Assoc. 2013;2: e004473. doi:10.1161/JAHA.112.004473.

47. Cook NR, Cohen J, Hebert PR, Taylor JO, Hennekens CH. Implications of small reductions in diastolic blood pressure for primary prevention. Arch Intern Med. 1995;155:701-09.

48. Whelton PK, He J, Appel LJ, Cutler JA, Havas S, Kotchen TA, Roccella EJ, Stout R, Vallbona C, Winston MC, et al. National high blood pressure education program coordinating committee. 
Primary prevention of hypertension: clinical and public health advisory from the national high blood pressure education program. JAMA. 2002;288:1882-88.

49. Bangalore S, Kumar S, Lobach I, Messerli FH. Blood pressure targets in subjects with type 2 diabetes mellitus/impaired fasting glucose: observations from traditional and bayesian random-effects meta analyses of randomized trials. Circulation. 2011;123:2799-810. doi:10.1161/CIRCULATIONAHA.110.016337.

50. Stamler J, Vaccaro O, Neaton JD, Wentworth D. Diabetes, other risk factors, and 12-yr cardiovascular mortality for men screened in the multiple risk factor intervention trial. Diabetes Care. 1993;16:434-44. 